\title{
IMPACT OF LEADERSHIP STYLES TOWARD EMPLOYEE ENGAGEMENT AMONG MALAYSIAN CIVIL DEFENCE FORCE
}

\author{
Fadillah Ismail* \\ Faculty of Technology Management and Business, Universiti Tun Hussein Onn Malaysia \\ Nishannthuni A/P Arumugan \\ Faculty of Technology Management and Business.Universiti Tun Hussein Onn Malaysia \\ Adibah Abdul Kadir \\ Faculty of Technology Management and Business, Universiti Tun Hussein Onn Malaysia \\ Adnan Ali Hassan Alhosani \\ Faculty of Technology Management and Business, Universiti Tun Hussein Onn Malaysia
}

\begin{abstract}
It is a fact that organization's success and failure heavily depend on employees and employee engagement is found as one of the important indicators to engage work force in any organization. It has been repeatedly discussed by researchers in the past years and it was established that employee engagement is affected by variation in leadership styles. Many drivers regarding employee engagement have been identified, thus making the concept of employee engagement clear and more understandable for the employer. It also impacts employee performance and wellbeing as found by the past researchers. Leadership style also play a significant role in employee engagement. Leadership style is usually associated with the engagement of an employee and became the most important driver that may create culture of employee engagement in the organization. Leadership style also helps to drive optimal level of productivity in an organization and maintain employee trust. This study aims to identify the engagement level of employees in Malaysian Civil Defense Force and its relationship with leadership style. This research used Multifactor Leadership Questionnaire (MLQ) as a research instrument. SPSS software package for social sciences version 22 was used to analyze the data in this study. Finding of this study shows that leadership styles have a significant impact on employee engagement especially transformational leadership has a significant relationship with employee engagement. Therefore, from the findings of this study, it is suggested for the future researchers to use the mix method in collecting data so that the findings will be more accurate and detailed and can be generalized.
\end{abstract}

Keywords: Leadership style, Employee engagement, Malaysian Civil Defense Force

Received: 17 May 2020

Accepted: 31 July 2021

https://doi.org/10.33736/ijbs.4294.2021

\footnotetext{
- Corresponding author: Faculty of Technology Management and Business, Universiti Tun Hussein Onn Malaysia, 86400 Batu Pahat, Johor, Malaysia. Email: fadillah@uthm.edu.my
} 


\section{INTRODUCTION}

Industrial Revolution and its advantages are proven for every country. It was helpful in upbringing the socioeconomic status of the countries. It was marked with four distinct phases: IR (Industrial Revolution) 1.0, 2.0, 3.0, and 4.0. Industrial Revolution is based on digitization which means that the industries depend on digital technologies. Smart factories concept means manufacturing system becomes smarter by using machines. This resulted in the decision-making task to be shifted from humans to technical system or machines (Olivier \& Maltais, 2017).

This Industrial Revolution resulted in economic growth, increased productivity, and production of high-quality good and services. This rapid advancement in digital technologies resulted in huge impact on the workforce management in many companies. According to the workforce management of Kronos Company, people or employees should be paid more attention from the management while chasing smart factory concept of Industry 4.0. In the new era of Industry 4.0, human resources management faced several challenges in the engagement of employee (Williamson, 2016). Employee engagement is among the top challenges faced by the organizations in this digitization era. It is because Industry 4.0 mostly depends on robotics technologies and less concerned about the employee performance which is an ultimate result of employee engagement. Employee's performance is crucial for an organization to become more innovative and successful. Hence, many successful companies are concerned about fostering a culture of engaged employees. According to Ferrer (2005) employee engagement is the degree of involvement of employees into their job. Employee engagement is an enormous task, and objective of every organization is to bring involvement, enthusiasm, and commitment of employees.

In this scenario, leadership is an important component that can help create employee engagement. Literature suggests that visionary leaders can create a culture of engagement among employees which helps to increase overall satisfaction and improve employee retention, drive optimal levels of profit and productivity, empowering employee, reducing turnover rate, strengthen employee trust (Wiley, 2010). Leadership style plays a significant part in developing an organization. Leadership is the capability to influence attitude of others. It also describe the competencies that a person has to control a group of employees in order to achieve organizational objectives. There are different styles of leadership as identified in the literature like, transformational leadership, transactional leadership, traditional leadership, laissez-faire, charismatic leadership, and servant leadership (Alsayed et al., 2012; Eagly, 2007; Wiley 2010).

Leadership style can influence employees and increase the employee engagement towards a better business achievement as found by Wiley (2010), who postulated that having a top position people can help an organization to build employee confidence, motivate employee performance, inspiring and improve employee engagement and drive innovation. The effectiveness of leadership styles and the level of employee engagement are two aspect that helps a company to achieve favorable outcomes (Voon et al., 2011).

\subsection{Research Background}

Malaysian Civil Defense Force (MCDF) is a civil defense agency which is known as "Angkatan Pertahanan Awam Malaysia" (APM). In the year of 1939, the Civil Defense activities in Malaysia were initiated by the British Government. In 1951, the Civil Defense Ordinance was enacted as a 
law, establishing civil defense as a national responsibility in the threat faced by the Malayan Emergency. The vision of MCDF is to become an efficient Civil Defense Force in society preparedness, community protection and disaster control. The mission of MCDF is to empowering people preparedness for national security and welfare. There are some units and divisions in MCDF for managing employees such as Force Management, Management Training, Management Services and Human Resources Management. Malaysian Civil Defense Force have trained leaders to motivate, share knowledge and influenced the followers to achieve their organizational objectives. They were trained well to become a leader with multi-talented personality, good communication skill and capability to attract subordinates with the skills. MCDF believes that multi-talented leadership can develop the grade of employee engagement. Multi-talented leaders must have multifactor leadership styles.

\subsection{Problem Statement}

Employee engagement can vary in different perspectives. Fresh graduated employees are expecting more from organizations such as high salary, modern facilities and so on. They seek for short-term careers in different organization with new expectation (Smith \& Markwick, 2009). A study conducted by Smith and Markwick (2009) shows that 30\% out of 150,000 employees in their study described themselves as being engage at work, $52 \%$ of them disengaged, and $18 \%$ is actively disengaged. Some companies faced the complication such as low productivity, inefficiency to meet performance goals, and poor innovation. This happen because more employees are not loyal to their job as well as to their organization in which they work. In previous research conducted by Gallup identified that more than $80 \%$ of British employees are not fully committed toward their job and organization, and a quarter of these are dissatisfied, rebellious and actively disengaged, showing no pleasure and zero dedication towards their job (Smith \& Markwick, 2009).

These issues surface because of the lack of effort and interventions on part of leadership. According to a recent study on leadership and employee engagement by HR.com shows that three-quarters of the respondents are of the view that there is a link between leadership style with employee engagement (Milhem et al., 2019). The toughest demand faced by the business leaders of numerous companies has been to ensure that when their workers check in daily, they not simply do their work physically but also be attached psychologically and emotionally (Bedarkar \& Pandita, 2014). Moreover, employee's engagement has become a central concern because it connects to attitude, like attendance, turnover, and organizational citizenship. The main challenges that employers are facing nowadays is lack of employee engagement with an organization. Workers should have the awareness that the company wants the best for them, and as an outcome they will maintain to do their best and not look for another organization. Employee engagement is determined according to the company has organized things and the way this is conveyed to the workers. This statement has been supported by the previous research by Aon Hewitt Consulting, only half of the workers are passive or actively disengaged. There are 30 percent of workers currently ready to leave their company whereas a large, disengaged force is not considering leaving their organization (Bedarkar \& Pandita, 2014).

Malaysia Civil Defense Force (MCDF) or Angkatan Perthahanan Awam (APM) is responsible to provide assistance when any disaster occurs. Another important task they need to undertake is 
carrying out the relief operations for providing safety to persons and properties and in case of looming disaster they provide protection to civilian population and are also responsible for helping the recovery victims after any disaster (Nazli \& Khairudin, 2018). In September 2020 MCDF chief commissioner Datuk Roslan Wahab reiterated that the MCDF is in dire need of more permanent employees to handle the challenges of tough duty during COVID-19 pandemic. Datuk Roslan said that, "Under the present situation, the APM needs to double the number of its permanent personnel to at least 3,000 nationwide". This situation clearly points towards the fact that in this emergency situation employee engagement is utmost necessary and to engage the current employees leadership has to play its role. Therefore, present study is an attempt to address this burning issue of employee engagement which is being faced by Malaysian Civil Defense Force or Angkatan Perthahanan Awam (APM).

\subsection{The Objective of this Study}

Three research objectives were formed for this study:

1. To identify level of employee engagement of staff of MCDF in Johor Bahru, Batu Pahat and Muar;

2. To investigate the relationship between type of leadership styles and employee engagement of MCDF staff in Johor Bahru, Batu Pahat and Muar;

3. To study the effect of multifactor leadership style towards employee engagement of staff of MCDF Johor Bharu.

\subsection{Scope of research}

This study was conducted at Malaysian Civil Defense Force (MCDF) which is located at Muar, Batu Pahat and Johor Bahru to study the effects of leadership styles in MCDF towards staff's engagement. Three styles of leadership such as laissez-faire, transactional leadership and transformational leadership were the target of this study. Present research targeted staffs of MCDF at Muar, Batu Pahat and Johor Bahru as respondents. The secondary data is referred on the relevant organization documents and the organization's PowerPoint presentation. The research of study conducted by using quantitative techniques and data analysis was analyzed by using SPSS software.

\subsection{Significance of Study}

The findings of this adds to body of knowledge on types of leadership styles towards employee engagement level. Leadership is the most important tool to attract employees to move forward and accomplish the company goals. Through this study, we can identify and help to develop the leadership style among leader at MCDF to attract the subordinates to follow his/ her directions. This research also helps to develop and improve the employee participation or involvement in the organization. In addition, the findings hopefully provided useful guidance, information and references for the other researcher who shall embark on further studies on related topics. Last but not the least, the findings of the study not only enhanced knowledge but also shed some light on the correlation and effect of the style of leadership and engagement of employee especially within Malaysia. 


\section{LITERATURE REVIEW AND FRAMEWORK DEVELOPMENT}

\subsection{Concept and Definition of Leadership}

According to Silva (2016), leadership is a particular character of an individual that can influence employees. Leader is defined as an individual who have a group of followers and who is holding the responsibility of leadership in an organization. Leader also is a person who set strategies, motivate their followers and, they create the aim and vision of a company and build a culture to succeed. Leaders also show their best performance to the followers and influence them by being as an example to their followers.

According to Confucius, a Chinese thinker who lived about 2500 years ago it was stated that leaders should be honorable and take care of the group around them (Silva, 2016). Confucius also mentioned that main idea of leader is to serve the people. According to Confucian Leadership theory, leaders think about the results of their behavior before acting or speaking when leading his team, unit, and overall organization (Low \& Ang, 2012). Leaders also have an ability to set goals and implement the goals with the help of their followers. Therefore, the organization's success depends on leadership of a leader. Furthermore, Leadership refers to a position or the process of influencing the followers to help reach the goals. There are different definitions from past researchers. Referring to Graham (1997), leadership is the capability to maneuver a team towards a common aim that would not be met if a leader had not been there (Val \& Kemp, 2012). Leadership impact can be seen in many areas like training and development process, motivation, performance assessment and management strategic planning. According to Kagan and Bownman (1997), leadership appears when there happens a fundamental problem. It is because the failure of the field to interpret "whether there is a specific set of competence correlate with leadership and bring out the important of skills" (Jones, 2007).

Leadership also influences the organizational performance, employee engagement and will help to improve the productivity. Based on Bass (2008) as cited in McCleskey (2014), the single interpretation of leadership depends on the researchers and is based on the problem or situation being studied. Leadership also defines as personal qualities or interpersonal influence, which gives direction and train the followers through a situation by the communication process to accomplish the vision and make the vision into company realities (Silva, 2016; Tannenbaum, Weschler and Massarik, 1961; Bennis \& Townsend, 1995). Based on our Prime Minister Y.A.B Tun Dr. Mahathir Bin Mohamad has mentioned that "to be a great leader, one needs to have good strategies, be knowledgeable and able to predict the future". Leadership is defined as personal qualities of an individual who can set strategies or create vision and influence their followers by their skills and character in positive manner to achieve the goals of an organization.

\subsection{Leadership Style}

Leadership styles attribute to persistent pattern of attitude that describe a leader (Nanjundeswaraswamy \& Swamy, 2014). Sometimes leadership is based on the leaders' characteristics and position they hold. Different leaders have different leadership styles. It happens when leadership changes in an organization. Leadership change is referring as the recruitment or 
selection of a new leader such as new president or manager or chairman of the board in an organization. The leadership styles might be different than the previous leaders. According to Iqbal et al. (2015) several issues are related to performance phenomena and how it influences or affects numerous variables such as leadership and type of leadership style. As we know there are three type of leadership style, which is transformational leadership, transactional leadership and laissez faire. According to Bass et al. (2003), leadership styles are divide into three types of leadership. There are nine components of model composed of contingent reward, individualized consideration, active management by exception, and passive management by exception, intellectual stimulation, inspirational motivation, idealized influence attribution, idealized influence behaviour, and laissezfaire (Yahaya \& Ebrahim, 2016).

\subsubsection{Transformational Leadership}

Transformational leadership is one of leadership style which triggers employees towards high-level needs explained in Maslow's hierarchy of needs by making workers conscious of the importance of undertaking company responsibility (Wang \& Hu, 2017). Transformational leaders are more to care about employees especially about their personal needs and development. The employees are also impressed, they respect, be loyal and are motivated by character of transformational leader. Employees also show improvement in work performance which is influenced by the personality and abilities of transformational leaders (Hampson \& Jowett, 2012). There are some mutual trust and values between leaders and employees in an organization and they collaborate along to reach the organization goals. Transformational leadership is also described as a leadership approach that can inspire positive changes in organization's culture, structure, and strategy. Individually, it generates positive and valuable transformation in the followers with the end objective of promoting followers into leaders. Based on the study of Geyer and Steyrer (1998), transformational leadership can bring enormous impact on employee's turnover intention (Wang \& $\mathrm{Hu}, 2017$ ). Transformational leadership has been rated by inspirational motivation, idealized influence, intellectual stimulation, idealized effect behavioral and employee consideration (Aunjum et al., 2017; Slehr \& Kueny, 2017; Suifan \& Al-Janini, 2017).

\subsubsection{Transactional Leadership}

According to the theory of Bass (1985) and Kark et al. (2018) explain that leadership under transactional style aims on controlling and engaging members and to satisfy their needs and demands. Transactional leaders bring out motivation by avoiding punishments or to prevent corrective actions. Transactional leadership focuses on results, conforms to the existing structure of an organization and measures success according to that organization's system of rewards and penalties. This shows that Transactional leadership style is related on expectation that employees are driven by the effective system of rewards and punishments. Meanwhile Wang and Hu (2017) stated that, this type of leadership based on transaction and a series of implicit contracts, where the leaders make immediate action to facilitate employee engagement on important matters. This is because leaders have the authority power and scope of responsibility in an organization. They are responsible for maintaining the routine by managing and facilitating employee's performance. Referring on Lapeña et al. (2017) this type of leadership focus on the roles including supervision and organization of daily progress within the organization. 


\subsubsection{Laissez Faire or Non-Leadership}

Laissez-Faire defines as leaders who provides the possibility of freedom and opportunity in defining goals and behavior to engage with organization. This type of leadership brings new work environment culture where the organization provide opportunities to the subordinates to participate in decision making. However, the group often lacks direction and delay in making final decision. It is because the leader hands over the responsibility and refuses to involve in the process of decision making. This situation often leads to failure and it effects the organization performance. It is not real leadership style, because of impact of social actors, whose activities were not coordinated, limited or formalized.

\subsection{Definition on Employee Engagement}

Most of the companies are attempting to create an environment to engage the employee as a key driver of success. Employee engagement is all about the emotional affinity or rapport with a company and the reaction they take to commit the organization's achievement; imply passion, cooperation, focus on productivity and outcomes (Allen, 2014). When an employee gets engaged to an organization, they will use discretionary effort. Discretionary efforts define as a willingness of an employee to go "above and beyond" the call of duty. For an example the employee volunteering for extra task or works, as one of the strategic to perform better in their job scope or helping others with heavy workloads.

Based on Macey and Schneider (2008), engaged employee has an effective and powerful liaison that effected job performance. Employee engagement also refers as independent involvement and satisfaction as well as enthusiasm for work. Based on Harter et al. (2002), when the worker is engaged, they are emotionally connected to others and cognitively towards the directions of the team. According to Kahn (1990), engagement defines to be psychologically and apart from a physical present while operating work roles. Employee engagement is appearing when the employees working with passion and using their talents to drive their talents to drive innovation for an organization success.

There are no single or general definition about the term of employee engagement (Markos \& Sridevi, 2010). Referring to Perrin (2003) stated that employee's engagement refers to eagerness and enthusiasm of employees in helping the company achieve their success. Engagement is affected by two components which involves emotional and rational element relating to the work they do and experience. It is believed that engagement impact psychological or affective state such as involvement in decision making, commitment to job, attachment to the organization and also performance construct such as effort, observable behavior, role performance, citizenship behavior, and also their attitude.

Based on the researchers Robinson et al. (2004), they acknowledged employee engagement also refers in the role of a positive behavior of an employee towards their organization. Employee engagement is an enormous task given to every organization. The organization must work to develop the culture of engagement which requires two-way relationship between employee and employer. Organizations where the engagement between an employer and employee should be practiced and both parties will be surprised on how it can change the relationship between the two parties. 
Referring to Sorenson (2013), there are three different levels relating to engagement which are actively engaged, actively disengaged and not engaged. Actively engaged refer to the high productive and happiest employee characterized with discretionary effort and commitment (Kahn, 1990). However, not engaged employees tend to focus only on completing assigned tasks rather than achieving the goals of the organization (Gallup, 2006). Non-engaged employees refer to be those who won't do more than their mere work performance. Besides, actively disengaged refers to the unhappy employees and demotivated at work and also disregard the performance set by the company. In conclusion, employee engagement is an emotion of an employee such as willingness, ability, commitment, positive attitude and who takes discretionary effort towards an organization's success.

\subsubsection{Dimensions of Employee Engagement}

Employee engagement can be measured in many ways to practices for a previous method. Feeling belonging and proud to be part of the company, likelihood to propose the organization to colleagues and family members, has high ambitions in the organization, these are the ways to measure traditional engagement in an organization. In this study, there are six dimensions of employee engagement. Feedback, opportunities and growth, purpose and direction, fairness, respect for employee and employee commitment. Feedback of an employee towards his organization is very important to get to know what the employee feels towards his organization. Employee engagement also provides the opportunity and growth of an employee in an organization. Employee also will engage to an organization when there is good purpose and direction, fairness and respect.

\subsection{Correlation between Leadership Style and Employee Engagement}

According to Hassell (2017), every organization is moving forward to develop an understanding and belief on the importance of motivation, encouraging, establishing, and connecting with all units in an organization to their leaders. A leader should be able to support employees to create a culture where people want to come to work, inspired to settle their task, feel proud of their company and take accountability and ownership for the business as if it were their own. This study investigated the understanding of relationship of leadership styles to employee engagement in the workplace.

Figure 1: Research Framework

\begin{tabular}{|c|c|}
\hline Leadership style & Employee engagement \\
\hline $\begin{array}{l}\text { Transformational } \\
\text { leadership }\end{array}$ & \\
\hline $\begin{array}{l}\text { Transactional } \\
\text { leadership }\end{array}$ & $\begin{array}{l}\text { Communication and } \\
\text { Leadership }\end{array}$ \\
\hline Laissez-faire & $\begin{array}{l}\text { Pay and Recognition } \\
\text { Training and Development }\end{array}$ \\
\hline
\end{tabular}




\subsection{Hypotheses Development}

A study conducted by Thisera and Sewwandi (2018) on the effect of transformational leadership towards employee engagement in the hospitality industry in Sri Lanka noticed that there is a beneficial impact of transformational leadership toward employee engagement. A few more studies also discovered that transformational leadership impacts positively on employee engagement (Breevaart et al., 2014; Datche \& Mukulu, 2015; Tims et al., 2011). Transactional leadership according to Popli and Rizvi (2016) had shown important relationship through the element of motivation in return for every achievement of the work earned by the employees by rewarding and awarding them. Leader with laissez faire leadership style rarely guide and advise their employee (Webb, 2007). Leader with this type of leadership style often assume that their employee knows everything. Van Eeden et al. (2008) shows that this type of leaders mostly failed to coordinate their employee; hence employee become apathetic, unmotivated, expressing bitterness or indignation towards the company and the leader which cause absenteeism, lower morale, and low productivity. Even though they have a large freedom in their work, they don't want to commit working more than they should (Tims et al., 2011).

\section{METHODOLOGY}

\subsection{Research Design}

Research design is a systematic plan, provided with framework that specifies the information collected and analysis phases about the study, also to ensure that the study is relevant to the problem and used economical procedure. In this research, type of research design that is used is quantitative approach. This is because quantitative approach is more reliable and prepared in multiple choice questions. The quantitative methods are focused on analytical or calculation analysis of data that can be collected through questionnaires, or by manipulating pre-existing case study data applying computing technique.

\subsection{Population and Sample}

Staffs at the Malaysian Civil Defense Force (MCDF) Johor was the target population for this study, and it refers to the permanent employees and volunteers' staffs at MCDF. This research has chosen Cluster Random Sampling which is the selecting respondents from the population into separate groups. The respondents are selected in Johor Bahru, Batu Pahat and Muar. The number of staffs in Johor Bahru is 82 staffs, Batu Pahat 47 staffs and in Muar are 97 staffs. It is to ensure that the sample size represents the entire MCDF population, Table 1 below shows the number of actual respondents required.

Table 1: Population and Sample Size of Respondents

\begin{tabular}{lcc}
\hline \hline District & Population & Sample Size \\
\hline Muar & 82 & 33 \\
Batu Pahat & 47 & 30 \\
Johor Bahru & 97 & 39 \\
\hline \hline
\end{tabular}


This study used the quantitative approach through the set of questionnaires, as a technique for data collection. The questionnaire used was constructed through literature review and adapted from previous researcher. There are three sections in this questionnaire and 70 items. First section related to respondent profile, such as age, race and education level. Section B is related to type of leadership style, while section $\mathrm{C}$ is about the employee engagement. Respondents were required to answer all questions based on the answer scale provided. The data obtained from questionnaire were analyzed using SPSS to answer the hypothesis and research questions.

\subsection{Research Instrument}

Device or tools that are used to collect input to achieve the objective of the study, answer the hypothesis and research question. This research used questionnaire as research tool to gather qualitative data as research instrument. A questionnaire is a data collection instrument which consist of a series of questions for the purpose of gathering information from respondents (Abawi, 2013). According to Polit et al. (2001), questionnaire is seen as one of effective tool to get important information and data which can test their attitude, feelings, knowledge and beliefs.

\subsubsection{Research Instrument on Demographic Questions}

Demographic questions are about personal information or background. In this study, there were six closed-ended questions that respondents had to answer which is about their gender, age, education level, working hours, management level, and years of working and professional qualification.

\subsubsection{Research Instrument on Leadership styles based on Expertise}

Leadership styles can be evaluated based on employee knowledge in executing their task. Leadership styles covered the Section B of the questionnaire. The researcher used the Six-Point Likert Scale (1-Not at all, 2- Rarely, 3-Sometimes, 4- Frequent, 5- Very Frequent) to rate each questionnaire item. The questions were adapted from the Multifactor leadership questionnaire based on Bass and Avalio (1985) research. This section consists of 39 questions.

This research used Multifactor Leadership Questionnaire (MLQ) as a way to obtain the data. The respondents were met in person as to ask them to fill in the questionnaire that had been printed. The MLQ is widely used for leveling leadership styles (transformational, transactional and laissezfaire). Multifactor Leadership Questionnaire contains five behavioral components for transformational leadership which is idealized impact, inspirational desire, intellectual stimulation, and individualized consideration. Transactional leadership consists of three behavioral components: contingent benefit, operating management by exception, and static management by exception. Laissez-faire is the non-leadership factor. Multifactor Leadership Questionnaire is also used to assess an outcome factor which is employee engagement.

\subsubsection{Research Instrument on Employee Engagement}

Employee engagement questionnaire in this study was adapted from a questionnaire developed by Croswell (2018) with 20 question items. Respondents should answer all questions in section c 
based on the five likert measurement scale (Strongly Disagree-1, Disagree-2, Somewhat Disagree3, Agree-4, and Strongly Disagree-5).

\subsection{Pilot study}

A preliminary trial of a research or more known as pilot study is a simple version of a full-scale study or called as feasibility study (Van Teijlingen and Hundley, 2002). In pilot study the questionnaire was distributed to fewer participants. Based on Van Teijlingen and Hundley (2001), one of the advantages of organizing a preliminary study is that it might give alarm warning about the primary research could fail if research protocols is not followed or whether proposed design or the tool are inappropriate or too difficult. A preliminary study is also useful to find unclear or uncertain items or question in survey tool. Before actual data being collected a pilot study need to work first with research instrument to know the level of reliability whether it is acceptable or not. The researcher picked randomly from 30 staffs of MCDF at Johor Bahru to determine the content of research instrument tool whether the value of acceptant is reliable and consistent. Pilot test is conducted to verify and identify any problem from the respondent about the set of questionnaires, especially about the verse, language, and meaning of the statement. Through the feedback provided researcher will make reasonable changes.

\subsubsection{Actual Study Reliability}

For the actual data, the numbers of respondents are 102 staffs of MCDF. The result has shown in the Table 2.

Table 2: Actual Test of Reliability of IV and DV

\begin{tabular}{lcccc}
\hline $\begin{array}{l}\text { Independent } \\
\text { Variable }\end{array}$ & $\begin{array}{c}\text { Alpha } \\
\text { Cronbach }\end{array}$ & $\begin{array}{c}\text { Number of } \\
\text { Question }\end{array}$ & $\begin{array}{c}\text { Number of } \\
\text { Respondents }\end{array}$ & Result \\
\hline Transformational & 0.861 & 22 & 102 & Good \\
Transactional & 0.881 & 12 & 102 & Good \\
Laissez-faire & 0.638 & 5 & 102 & Accepted \\
$\begin{array}{l}\text { Multifactor } \\
\text { Leadership }\end{array}$ & 0.825 & 39 & 102 & Good \\
Employee & 0.955 & 20 & 102 & Good \\
Engagement & & & & \\
\hline \hline
\end{tabular}

Table 2 above shows the result of actual reliability test. Based on the Cronbach's alpha values, all variables studied showed good and acceptable values. According to Ramayah, Samat and Lo (2011), the value of Alpha Cronbach coefficient values of more than 0.7 are considered good but values of more than 0.5 are still acceptable.

\subsection{Data Analysis Methods}

The method of data analysis used in the research process is determined by the research method used. Data analysis method is the stage of the research process in which the data collected can be processed to formulate a conclusion. Thus, selecting or using the right analytical techniques is important to address the research objectives and generate meaningful arguments for discussion. 
Table 3: Analysis of Objective

\begin{tabular}{ll}
\hline \hline \multicolumn{1}{c}{ Research objectives } & \multicolumn{1}{c}{ Analysis } \\
\hline $\begin{array}{l}\text { To measure the level of employee engagement of } \\
\text { staff of MCDF Johor Bharu }\end{array}$ & Frequency, Percentage and Mean Score. \\
& \\
$\begin{array}{l}\text { To determine the correlation between multifactor } \\
\text { leadership style and employee engagement of staff of } \\
\text { MCDF Johor Bharu }\end{array}$ & $\begin{array}{l}\text { Correlation } \\
\text { (Pearson) }\end{array}$ \\
$\begin{array}{l}\text { To study the effect of multifactor leadership style } \\
\text { towards employee engagement of staff of MCDF }\end{array}$ & $\begin{array}{l}\text { Regression } \\
\text { Johor Bharu }\end{array}$ \\
\hline \hline
\end{tabular}

\section{DATA ANALYSIS AND RESULTS}

\subsection{Demographic Analysis}

This study involves 43 male and 11 females. This means there are $42.2 \%$ of males and 57.8 of female staffs participated in this study. Among all, female respondents are higher than male respondents. Age categories are divided into four groups namely, age between below 20 years, age between 20 up to 29 years, age between 30 up to 39 years, age between 40 until 49 years and age 50 years and above. This study found that no respondents aged between 40 and 49 years old. $2.9 \%$ (3) of the respondents' age below 20 years old, $69.6 \%$ (71) age between 30 to 39 years old, $26.5 \%$ (27) age between 50 years old and above 1\% (1). Among all, age between 20 to 29 years has the highest number of respondents while age 50 years and above has the lowest number of respondents. The racial background in this study is divided into four categories which are Malay, Chinese, Indian, and others. Indian respondents only accounted for $1 \%$, while no Chinese respondents were involved in this study. Among all, Malay respondents were the highest with $96.1 \%$, followed by $2.9 \%$ (3) of them from other races. There are five categories in highest academic qualification involved in this survey which are SPM/STPM, Diploma, Degree, Masters and PHD. The study found that most of the respondents had education in SPM/STPM level with a total number of 56 which are about 54.9\%. The second highest group is the educational level of Diploma, which had a total of 29 respondents or $28.4 \%$. There are $16.7 \%$ of respondents from the educational level of Degree.

There are 32.4\% (33) of the respondents working at Muar, 29.4\% (30) are working at Batu Pahat and $38.2 \%$ (39) are working at Johor Bahru. Among all, staffs from Johor Bahru were the highest respondents while staffs from Batu Pahat are the lowest respondents. There are four categories involved in this survey which are less than one year, one to two years, three to five years and more than six years of working experience. The majority of the respondents are having 3 to 5 years of experiences in MCDF which are 30 staffs or $29.4 \%$. The second highest group is having experiences more than 6 years which had a total of 26 respondents or $25.5 \%$. There are $24.5 \%$ of respondents which are 25 staffs having 1 to 2 years of working experiences and 21 staffs are having less than 1 year experience which is $20.6 \%$. 
Categories of management in this survey divided into three that is top management, middle level management and lower level management. There are $10.8 \%$ (11) of respondents from top level of management. $40.2 \%$ (41) of respondents are from middle level of management. 49\% (50) of respondents are from lower level of management. Among all, lower level management has the highest number of respondents while top level management has the lowest number of respondents.

\subsection{Descriptive Analysis}

In this part there is findings about the transformational leadership style. Respondents who are staffs of MCDF have given their responses from several aspects. This study uses mean and standard deviation values through descriptive analysis to interpret the meanings for measurement items under transformational leadership. The respondent's scale the rating based on their experience how they treat their subordinates. The five-point Likert scale ranging from 1 (not at all) to 5 (very frequent) was used to rank each component of the transformational leadership.

Value at $3.37(\mathrm{SD}=0.516)$ is an overall mean score of transformational leadership which categorized in moderate level. This level indicate that the respondents make others feel good to be around with value of mean score at $3.71(\mathrm{SD}=0.916)$ even some of them claimed that they have less tendency to go above personal interests due to the priority of the group which has the lowest mean score $2.843(\mathrm{SD}=1.115)$.

Statement that the leader will consider employee has a variety of needs, capability and ambition from others show as second highest of mean score with value at 3.73 ( $\mathrm{SD}=0.886)$. The following items that respondents have support is they will straightforward tell what we could and should do is having the mean score $3.70(\mathrm{SD}=0.755)$, they will consider the moral and ethical consequences of decisions which is the mean score 3.62 ( $\mathrm{SD}=0.8806)$, they express courage that objective will be success which is mean score 3.62 ( $\mathrm{SD}=0.8793)$, they help others develop themselves which is the mean score 3.58 ( $\mathrm{SD}=0.9692$ ) and encourage others to come out with new strategy in addressing existing issues which is the mean score $3.52(\mathrm{SD}=0.8644)$.

Besides that, the research outcome also shows $42 \%$ of the respondents agreed for they seek different perspectives when solving problems frequently which is the mean score 3.48 $(\mathrm{SD}=0.8644)$. Leaders talk enthusiastically about what need to be accomplished is agreed by $41.2 \%$ of respondents, they do frequently which is the mean score 3.48 ( $\mathrm{SD}=0.887$ ). Next is the $43 \%$ of leaders sometimes let others know how they think they are doing with the mean score of 3.36 $(\mathrm{SD}=0.8987)$ and others are proud to be associated with them which is the mean score is 3.36 $(\mathrm{SD}=0.9025)$. There are also $37.3 \%$ of respondents agreed that they create appealing figure about what they can do frequently at the same $35.3 \%$ of respondents agreed that they do sometimes with the mean score $3.34(\mathrm{SD}=0.928)$.

In addition, the following items are the lowest mean score than other items. There are some leaders who teach others to see things from a different perspective with mean score $3.27(\mathrm{SD}=1.035)$, others have complete faith in them which is the mean score $3.25(\mathrm{SD}=1.012)$, leaders get other to rethink ideas that they had never asked previously which is the mean score 3.22 ( $\mathrm{SD}=0.843$ ), some leaders commit with special attention to others who seem rejected with mean score 3.15 $(\mathrm{SD}=0.849)$, a few leaders spend time in coaching and train with mean score $3.09(\mathrm{SD}=1.127)$, leaders act in ways that build others respect for them with mean score $3.049(\mathrm{SD}=1.093)$ and some 
leaders communicate about the most significant values and beliefs that the mean score of 3.00. $(\mathrm{SD}=0.912)$

In the questionnaire this part is findings about the transactional leadership style. Respondents who are staffs of MCDF have given their responses from several aspects. The descriptive analysis was employed to illustrate mean and standard deviation values of the transactional leadership. The respondent's scale the rating based on their experience how they treat their subordinates. The five point Likert scale ranging from 1 (not at all) to 5 (very frequent) was used to rank each item of the transactional leadership.

The overall mean score of transformational leadership is $3.29(\mathrm{SD}=0.5224)$ which categorized in moderate level. The highest mean score for transactional leadership style is leaders focus and pay attention when facing with accusation, fault and failures with mean score of $3.61(\mathrm{SD}=0.720)$ and the leaders satisfied when workers meet the minimum requirement standards which is the same mean score value 3.61 $(\mathrm{SD}=0.822)$. The item with lowest mean score for transactional leadership is the leaders wait for the thing goes wrong before taking action which is the mean score is 2.51 $(\mathrm{SD}=0.972)$.

The second highest of mean score is 3.47 ( $\mathrm{SD}=0.898)$ which leaders' express satisfaction when other meet expectation. There are $48 \%$ leaders agreed sometimes as long as things are working, they do not try to change anything which is the mean score is 3.41 ( $\mathrm{SD}=0.894)$. Leaders also discuss specific terms who is responsible for achieving performance goal with mean score $3.40(\mathrm{SD}=0.870)$.

In addition, the items the lowest mean score than other items are leader express their work expectations to ensure employee rewarded with mean score $3.33(\mathrm{SD}=1.028)$ and leaders point out to what others can get for what they achieve with mean score of $3.33(\mathrm{SD}=0.916)$. Moreover, leaders inform others the requirement they have to know to perform their tasks with the mean score 3.30 ( $\mathrm{SD}=0.768)$, leaders provide benefit/ give appreciation when others achieve their objective/aim $3.24(\mathrm{SD}=1.138)$, leaders direct their attention against failures to meet specific requirement with mean score $3.13(\mathrm{SD}=0.8708)$ and leader point that he/she is a firm believer in "If it aren't broke, don't fix it" is with the mean score $3.12(\mathrm{SD}=0.972)$

Findings about the Laissez-faire leadership style. Respondents who are staffs of MCDF have given their responses from several aspects. To illustrate mean and standard deviation values of the Laissez-faire leadership this study uses descriptive analysis. The respondent's scale the rating based on their experience how they treat their subordinates. The five-point Likert scale ranging from 1 (not at all) to 5 (very frequent) applied to rank each component of the transactional leadership.

The overall mean score of laissez-faire leadership is $3.04(\mathrm{SD}=0.5576)$ which categorized in moderate level. The highest mean score for laissez-faire leadership style is whatever others want to do is $\mathrm{OK}$ with me with mean score of $3.42(\mathrm{SD}=0.789)$. The item with lowest mean score for transactional leadership is the leaders are found to be avoiding getting involved when important issues arise which is the mean score is 2.33 ( $\mathrm{SD}=0.968$ ). The second highest of mean score is 3.26 $(\mathrm{SD}=0.9742)$ which is the leader ask no more of others than what is essential. Moreover, leader is content to let others continue working in the same ways always with the mean score value is 3.25 
$(\mathrm{SD}=0.938)$ and leaders provide immediate feedback on important matters or urgent questions which has the mean value $2.95(\mathrm{SD}=1.018)$.

\subsection{Descriptive analysis for Employee Engagement}

In the questionnaire this part is findings about the employee engagement. Respondents who are staffs of MCDF have given their responses from several aspects. The descriptive analysis was employed to illustrate mean and standard deviation values of the employee engagement. The respondent's scale the rating based on their experience how they engaged in the organization. The five-point Likert scale ranging from 1 (strongly disagree) to 5 (strongly agree) was used to rank each item of the employee engagement.

The overall mean score of employee engagement is $3.63(\mathrm{SD}=0.550)$ which categorized in moderate level. The highest mean score for employee engagement is the company motivates me to go above and beyond in the employee role with mean score of 3.91 ( $\mathrm{SD}=0.760$ ). The item with lowest mean score for employee engagement is their pay is linked to my performance which is the mean score is $2.71(\mathrm{SD}=1.361)$.

The second highest of mean score are $3.86(\mathrm{SD}=1.034)$ which is the employee find his/her everyday work challenging and interesting, their leader gives them the opportunity to try new things in my role which align with my career goal with mean score of $3.83(\mathrm{SD}=0.797)$, the employee have an understanding of my career path at this company with the mean score of $3.7941(\mathrm{SD}=0.735)$, the employee have confidence in this company's senior leadership team 3.79 ( $\mathrm{SD}=0.813)$, they are able to take advantage of further development opportunities on their team $3.77(\mathrm{SD}=0.855)$, the employee have the training I need to be successful in my role $3.76(\mathrm{SD}=0.7601)$, the senior leadership team has communicated a vision for the future that motivates the employee with the mean score $3.74(\mathrm{SD}=0.961)$

In addition, some respondents agreed that they propose to provide a new perspective on the tasks assigned to them with mean score 3.73 ( $\mathrm{SD}=0.807$ ), they also see their will remain in this company for another two years with the mean score 3.73 ( $\mathrm{SD}=0.834$ ), as an employee they proud to know where and with whom they work to with mean value $3.67(\mathrm{SD}=0.899)$, the employee are given a role in decision making that affect him/her with the mean value $3.67(\mathrm{SD}=0.905)$.

Moreover, there are spaces and channels where two-way communication is practiced within the organization with the mean value 3.67 ( $\mathrm{SD}=0.894$ ), the employees are constantly being provided with information by leaders on current issues related to organizational with the mean value 3.65 $(\mathrm{SD}=0.992)$, the employee would suggest this company to others including family members as a preferred workplace with the mean value $3.54(\mathrm{SD}=0.852)$, they are good at training up new employees in this company 3.49 ( $\mathrm{SD}=0.941)$, employee get positive reaction and encouragement from leader for good work progress 3.37 ( $\mathrm{SD}=0.831)$, the employee receives fairly payment with the mean value $3.23(\mathrm{SD}=1.142)$. 


\subsection{Correlation Analysis}

Table 4: Correlation between Transformational Leadership and Employee Engagement

\begin{tabular}{ccc}
\hline \hline & & Employee engagement \\
\hline Transformational & Pearson Correlation $(\mathrm{r})$ & $.310^{*}$ \\
Leadership & Sig. (2-tailed) & 0.002 \\
& $\mathrm{~N}$ & 102 \\
\hline
\end{tabular}

*Correlation is significant at the 0.05 level (2-tailed)

Table 4 shows the results of the correlation analysis using Pearson's correlation coefficient between variables of transformational leadership style and employee engagement at MCDF. Research found that the $\mathrm{p}$ values is less than 0.05 of significant level but it shows a significant relationship $(r=0.002, p<0.05)$. However, the findings from the Pearson's correlation coefficient analysis recorded a weak relationship between those two variables with value 0.310 . The findings of this study, in fact, explain that employee engagement levels are high when MCDF adopts a transformational leadership style.

Table 5: Correlation between Transactional Leadership and Employee Engagement

\begin{tabular}{lcc}
\hline \hline & & Employee engagement \\
\hline Transactional Leadership & Pearson Correlation & $.230^{*}$ \\
& Sig. (2-tailed) & 0.020 \\
& $\mathrm{n}$ & 102 \\
\hline *Correlation is significant at the 0.05 level (2-tailed) &
\end{tabular}

The findings of the study related to the relationship between transactional leadership and employee engagement are shown in table 5 above. As we can see, significant level is at 0.05 , while p value of the transactional leadership and employee engagement is 0.020 , however it is a significant relationship. But if referred to Pearson's correlation coefficient it shows a low and positive correlation between these two variables. This gives the impression that the implementation of transactional leadership style practice at MCDF towards employee engagement is high. It can be concluded that alternative hypothesis in this research is accepted after it has been proven that the variables studied are related.

Table 6: The Relationship between Laissez Faire Leadership and Employee Engagement

\begin{tabular}{ccc}
\hline \hline & & Employee engagement \\
\hline Laissez faire Leadership & Pearson Correlation & $-0.440^{*}$ \\
& Sig. (2-tailed) & 0.660 \\
& $\mathrm{n}$ & 102 \\
\hline \hline
\end{tabular}

${ }^{*}$ Correlation is significant at the 0.05 level (2-tailed)

Table above show the results analysis of the study, related relationship towards laissez faire leadership and employee engagement among employee at MCDF in certain selected district. Based on the table 7 , it is found the value of $\mathrm{p}$ is more than 0.05 of significant level between laissez faire leadership and employee engagement. Finding also indicate the relationship is not significant $(r=$ 
$0.660, \mathrm{p}<0.05)$. Nevertheless, the analysis recorded the value of Pearson's correlation coefficient is -0.440 that interpreted a low correlation. Besides that, this study also found negative relationship between laissez faire leadership and employee engagement among employee at MCDF. This explains the practice of the laissez faire leadership style by the MCDF has led to low employee engagement. Thus, the conclusion of this finding proves that the alternative hypothesis is accepted with evidence showing that there is no relationship between the two variables.

\subsection{Regression Analysis for Transformational Leadership, Transactional Leadership, Laissez Faire and Employee Engagement}

Regression analysis conducted based on questionnaire answered by staffs of MCDF. There are three types of simple linear regression. The first linear regression is Transformational leadership as independent variable and Employee Engagement as dependent variable. The second type of linear regression is Transactional leadership as independent variable and Employee Engagement as dependent variable. Lastly the third type of linear regression is Laissez-faire leadership as independent variable and Employee Engagement as dependent variable. The Beta values were shown in Model.

\subsubsection{Regression Analysis for Transformational Leadership and Employee Engagement}

Table 7: Determination of Coefficient for Transformational Leadership and Employee Engagement

\begin{tabular}{ccccc}
\hline \hline \multicolumn{5}{c}{ Model Summary } \\
\hline \multirow{2}{*}{ Model } & $\mathrm{R}$ & R Square & Adjusted R & Std. Error of the \\
1 & $.310^{\mathrm{a}}$ & 0.096 & Square & Estimate \\
& & & 0.087 & 0.56835 \\
\hline
\end{tabular}

a. Predictors: (Constant), Transformational

b. Dependent Variable: Employee Engagement

From Table 7 , the $\mathrm{R}$ square $\left(\mathrm{R}^{2}\right)$ value is 0.096 , which means $9.6 \%$ of variance in change dependent variable (Employee Engagement) are due to change by independent variable (Transformational).

\subsubsection{Regression Analysis for Transactional Leadership and Employee Engagement}

Table 8: Determination of Coefficient for Transactional Leadership and Employee Engagement

\begin{tabular}{clrrr}
\hline \hline & \multicolumn{4}{c}{ Model Summary } \\
Model & $\mathrm{R}$ & $\mathrm{R}$ Square & $\begin{array}{c}\text { Adjusted R } \\
\text { Square }\end{array}$ & $\begin{array}{c}\text { Std. Error of } \\
\text { the Estimate } \\
1\end{array}$ \\
\hline \hline
\end{tabular}

a. Predictors: (Constant), Transactional

b. Dependent Variable: Employee Engagement

From Table 8 , the $\mathrm{R}$ square $\left(\mathrm{R}^{2}\right)$ value is 0.053 , which means $5.3 \%$ of variance in change dependent variable (Employee Engagement) are due to change by independent variable (Transactional). 


\subsubsection{Regression Analysis for Laissez-faire Leadership and Employee Engagement}

Table 9: Determination of Coefficient for Laissez-faire Leadership and Employee Engagement

\begin{tabular}{ccccc}
\hline \hline \multicolumn{5}{c}{ Model Summary } \\
\hline Model & $\mathrm{R}$ & $\mathrm{R}$ & Adjusted R & $\begin{array}{c}\text { Std. Error of } \\
\text { the Estimate }\end{array}$ \\
& & Square & Square & 0.59720 \\
\hline
\end{tabular}

a. Predictors: (Constant), Laissez-faire

b. Dependent Variable: Employee Engagement

From Table 9, the R square (R2) value is 0.002 , which means $2 \%$ of variance in change dependent variable (Employee Engagement) are due to change by independent variable (Laissez-faire).

\section{DISCUSSION, RECOMMENDATION AND CONCLUSION}

\subsection{Discussion}

From 102 of the total respondents, 43 of them are male and 59 of them are female. The findings compromised that $96 \%$ of the respondents were Malay. Moreover, most of the respondents participated in this research among those in the age group between 20 up to 29 years old. Most respondents in this study were from SPM/STPM qualification with total number of 56 respondents. In addition, most of the respondents are having three to five years working experiences in MCDF.

According to the study, the first objective is to investigate the level of employee engagement in MCDF at Muar, Batu Pahat and Johor. As proposed, there are few elements in employee engagement such as engagement, autonomy career progression, communication and leadership, pay and recognition and training and development. In this study, the employee engagement level retained by the employees is at the moderate level. Data Analysis shows that, MCDF organization concern about the employee engagement.

Referring on the first element, staffs are truly engaged because the company encourages and give support to motivate their employee to go above and beyond in the role. So, employees can improve their performance because employee's performance depends on motivation. These findings are supported by Dobre (2013), showed that the employees will achieve their target at working place by motivating them. The employees also can improve their skills by working in that organization in two years' time. Most employees say they are proud of others knowing where their organization works.

This finding proves that organizations and their employees are engaged together. This statement supported by Allen (2014), mentioned that an employee who have an emotional connection to their work place and work with passion are truly engaged with an organization.

Next is career progression. The employees also have improved their career progresssion by finding challenges and interest in their work. Career development or career growth is among the significant factors for employee to keep them engaged. According to Liu et al. (2017), career growth has a significant positive impact on employee engagement. Moreover, their leaders also provide and give 
new exposure to employees through job enlargement that aligns with their career path. The employees also have an understanding about their job scope and their career path at this organization.

In addition, communication and leadership also play important role in employee engagement. Staffs in MCDF expresses their belief and confidence towards existing leadership team. Where they assert that leadership motivates and always support them to achieve organizational goals. However, the results show a moderate level of employee engagement. Moreover, character and actions of the leaders can enhance employee engagement Leaders should openly communicate with the employees such as treat employees with respect, support employees to increase their potential to gain employee engagement (Zahid \& Ozyapar, 2017).

Stand on hypothesis one, the study shows that correlation between transformational leadership and employee engagement is positive. It is because the employee agreed that the transformational leaders make others feel good to be around them. This statement is supported by (Ahmad et al., 2014) which is transformational leaders always want to inspire their subordinates and be a role model to them. The leaders also realize that everyone has different requirement, needs, abilities and desire from others. Next, the leaders also play role as transformational leaders who state with simple sentence what we can do and need to do, and they will reflect on the moral and ethical cost and effect of outcome. Moreover, the leaders help others develop themselves and they are encouraging others to determine about previous issues in new approach.

Based on hypothesis two, the study displayed that relationship between transactional leadership and employee engagement is negative. However, few of them agreed that transactional leadership style compared to transformational leadership. It is because, transactional leadership styles followed by leaders who concentrate and give full consideration on facing with accusation, problems, and fault and the leaders complacent when others reach minimum requirement.

Based on hypothesis three, result indicate that correlation between employee engagement and laissez-faire is weak. The laissez-faire leadership style is followed by certain leaders which show that whatever others want to do is OK with the leader. There are some leaders who do not expect more than what is important and should be given.

Transformational leadership mainly play roles in employee engagement. Based on the findings of this study, it shows that the leaders at MCDF are following transformational leadership behavior on employee engagement. It is because the employee agreed that the transformational leaders create others to feel comfortable when they are around them. The leaders also realize every one of them has different needs, capability, and motivation from others. Next the leaders also play role as transformational leaders who conveys with simple sentences that are easy to understand what needs to be done, and they will think of the cost and effect of each decision. Moreover, the leaders help others develop themselves and they are encouraging everyone to think about issues and problem in new approach.

\subsection{Conclusion and Recommendation}

This study has been successful to prove that there is an effect of leadership style towards employee engagement in MCDF in Johor Bahru, Batu Pahat and Muar. In several areas recommendations for 
the forthcoming research are highlighted by the researcher that intended to provide future research directions to the other researchers. This study used questionnaire which is quantitative method to collect data. Thus, the researcher suggests that future studies could combine both methods of data collection which are quantitative and qualitative. Observation and interview are the examples of qualitative data collection. The following recommendations are offered to the Malaysian Civil Defense Force (MCDF) in Batu Pahat, Muar and Johor Bahru, according to finding, some of the respondents claimed that most them are following transformational leadership to lead their subordinates. Leaders in MCDF need to build a good relationship with the followers by getting to know the followers needs, goals and interest. Moreover, the leaders can create supportive and friendly work environment that could enhance the subordinate's welfare.

Empower and strengthen the level of employee engagement is a vital issue on the management plan in most competitive organizations. A better employee engagement has been shown resulting in organizational success in term of profitability, productivity, and customer loyalty, reduce absenteeism among employee and lower turnover rate. Money is not the priority factor to motivated employee, but employees now are more looking on meaning in their work, fulfillment, engagement in workplace, and empowerment in their task. Leadership determines excellent organizational performance and as leading factor in the development of work force it would help to encourage employee engagement. Our study confirms the link and effect between the engagement of employee and type of leadership style as supported by previous research.

\section{REFERENCES}

Abawi, K. (2013). Data Collection Instruments (Questionnaire \& Interview). https://www.gfmer.ch/SRH-Course-2012/Geneva-Workshop/pdf/Data-collectioninstruments-Abawi-2013.pdf

Ahmad, F., Abbas, T., Latif, S., \& Rasheed, A. (2014). Impact of Tranformational Leadership on Employee Motivation in Telecommunication Sector. Journal of Management Policies and Practices, 2, 11-25.

Allen, M. (2014). Employee Engagement - A Culture Change. The Insights Group Ltd. https://www.insights.com/media/1091/employee-engagement-a-culture-change.pdf

Alsayed, A. K., Motaghi, M. H., \& Osman, I. B. (2012). The Use of the Multifactor Leadership Questionnaire and Communication Satisfaction Questionnaire in Palestine: A Research Note. International Journal of Scientific and Research, 2, 2250-3153.

Aunjum, A. H., Abbas, G., \& Sajid, M. (2017). Transformational leadership and employee motivation in banking sector of Pakistan. Advances in Economics and Business, 5(9), 487494. https://doi.org/10.13189/aeb.2017.050901.

Bass, B. M. (1985). Leadership and performance beyond expectation. New York: Free Press.

Bass, B., \& Avolio, B. (1995). MLQ multifactor leadership questionnaire. Mind Garden.

Bass, B. M., Avolio, B. J., Jung, D. I., \& Berson, Y. (2003). Predicting unit performance by assessing transformational and transactional leadership. Journal of applied psychology, 88(2), 207-218. https://doi.org/10.1037/0021-9010.88.2.207

Bedarkar, M., \& Pandita, D. (2014). A study on the drivers of employee engagement impacting employee performance. Procedia - Social and Behavioral Sciences, 133, 106-115. https://doi.org/10.1016/j.sbspro.2014.04.174 
Bennis, W., \& Townsend, R. (1995). Reinventing leadership: Strategies to empower the organization. NY: Harper Business.

Breevaart, K., Bakker, A., Hetland, J., Demerouti, E., Olsen, O., \& Espevik, R. (2014). Daily transactional and transformational leadership and daily employee engagement. Journal of Occupational and Organizational Psychology, 87(1), 138-157.

Croswell, A. (2018). 20 employee engagement survey questions every company should ask. Culture Amp. https://www.cultureamp.com/blog/employee-engagement-survey-questions

Datche, A. E., \& Mukulu, E. (2015). The effects of transformational leadership on employee engagement: A survey of civil service in Kenya. Issues in Business Management and Economics, 3(1), 9-16.

Dobre, O.-I. (2013). Employee motivation and organizational performance. Review of Applied Socio-Economic Research, 5(1), 53- 60.

Eagly, A. (2007). Female Leadership Advantages and Disadvantages: Resolving the Contradiction. Psychology of Women Quarterly, 31(1), 1-12.

Ferrer, J. (2005). Employee Engagement: Is it Organizational Commitment Renamed? Victoria University of Technology Working Paper Series No 8/2005. https://vuir.vu.edu.au/123/1/wp8_2005_ferrer.pdf

Gallup. (2006). Who's Driving Innovation at Your Company? The Gallup Management Journal. https://news.gallup.com/businessjournal/24472/whos-driving-innovation-yourcompany.aspx

Geyer, A., \& Steyrer, J. (1998). Messung und erfolgswirksamkeit transformationaler führung. German Journal of Human Resource Management, 12(4), 377-401. https://doi.org/10.1177/239700229801200401

Graham, J. (1997). Outdoor leadership: Technique, common sense \& self-confidence. The Mountaineers Books.

Hampson, R., \& Jowett, S. (2012). Effects of coach leadership and coach-athlete relationship on collective efficacy. Scandinavian Journal of Medicine \& Science in Sports, 24(2),454460. https://doi.org/10.1111/j.1600-0838.2012.01527.x.

Harter, J. K., Schmidt, F. L., \& Hayes, T. L. (2002). Business-unit-level relationship between employee satisfaction, employee engagement, and business outcomes: a meta-analysis. Journal of applied psychology, 87(2), 268-279. https://doi.org/10.1037/00219010.87.2.268

Hassell, B. (2017, February 27). The Importance of Inspirational Leadership. Chief Learning Officer. https://www.clomedia.com/2017/02/27/importance-inspirational-leadershipreshaped-world/

Iqbal, N., Anwar, S., \& Haider, N. (2015). Effect of Leadership Style on Employee Performance. Arabian Journal of Business and Management Review, 5(5), 1000146.

Jones, M. (2007, November). What Is A Leader, Anyway? Exchange magazine, 74-77. https://childcareexchange.com/library/5017874.pdf

Kagan, S. L., \& Bowman, B. T. (1997). Leadership in Early Care and Education. NAEYC, 1509 16th Street, NW, Washington, DC 20036-1426 \$9).

Kahn, W. A. (1990). Psychological conditions of personal engagement and disengagement at work. Academy of management journal, 33(4), 692-724. https://doi.org/10.5465/256287

Kark, R., Dijk, D., \& Vashdi, D. R. (2018). Motivated or Demotivated to Be Creative: The Role of Self-Regulatory Focus in Transformational and Transactional Leadership Processes. Applied Psychology, 67(1), 186-224. https://doi.org/10.1111/apps.12122 
Lapeña, L. F. R., Tuppal, C. P., Loo, B. G. K., \& Abe, K. H. C. (2017). Transformational and transactional leadership styles of nurse managers and job satisfaction among Filipino nurses: A pilot study. Nurse Media Journal of Nursing, 7(2), 65-78.

Liu, J., He, X., \& Yu, J. (2017). The Relationship between Career Growth and Job Engagement among Young Employees. Open Journal of Business and Management, 5(1), 83-94. https://doi.org/10.4236/ojbm.2017.51008

Low, P. K. C., \& Ang, S. L. (2012). Confucian Leadership and Corporate Social Responsibility (CSR), the Way Forward. Asian Journal of Business Research, 2(1), 85-108.

Macey, W., \& Schneider, B. (2008). The Meaning of Employee Engagement. Society for Industrial and Organizational Psychology, 1, 3-30.

Markos, S., \& Sridevi, M. (2010). Employee Engagement: The Key to Improving Performance. International Journal of Business and Management, 5(12), 89-96. https://doi.org/10.5539/ijbm.v5n12p89

Milhem, M. M. A., Muda, H., \& Ahmed, K. (2019). The Effect of Perceived Transactional Leadership on Employee Engagement in Palestinian ICT industry. Journal of Advance Research In Business And Management Studies, 14(1), 42-51. https://www.akademiabaru.com/submit/index.php/arbms/article/view/1325/474

McCleskey, J. (2014). Situational, transformational, and transactional leadership and leadership development. Journal of Business Studies Quarterly, 5(4), 117-130.

Nanjundeswaraswamy, T. S., \& Swamy, D. R. (2014). Leadership styles. Advances in management, 7(2), 57-62.

Nazli, N. N. N. N., \& Khairudin, S. M. H. S. (2018). The factors that influence transfer of training and its effect on organizational citizenship behaviour: Evidence from Malaysia Civil defence force. Journal of Workplace Learning, 30(2), 121-146. https://doi.org/10.1108/JWL-09-2017-0080

Olivier, P., \& Maltais, B. (2017). Industry 4.0: The New Industrial Revolution. Are Canadian manufacturers ready? Business Development Bank of Canada. https://bridgr.co/wpcontent/uploads/2017/06/bdc-etude-manufacturing-en.pdf

Perrin, T. (2003). Working Today: Understanding What Drives Employee Engagement. The 2003 Towers Perrin Talent Report U.S Report. https://studylib.net/doc/12886509/understanding-what-drives-employee-engagementworking-tod...

Polit, D. \& Hungler, B. (1997). Essentials of nursing research: methods, appraisal, and utilization $\left(4^{\text {th }} \mathrm{ed}\right)$. Philadelphia: Lippincott Williams and Wilkins.

Polit, D. F., Beck, C. T., \& Hungler, B. P. (2001). Essentials of Nursing Research:Methods, Appraisal and Utilization (5 th ed). Philadelphia: Lippincott Williams \& Wilkins.

Popli, S., \& Rizvi, I. A. (2016). Drivers of Employee Engagement: The Role of Leadership Style. Global Business Review, 17(4), 965-979. https://doi.org/10.1177/0972150916645701

Ramayah, T., Samat, N., \& Lo, M. C. (2011). Market Orientation, service quality and organizational performance in service organizations in Malaysia. Asia-Pacific Journal of Business Administration, 3(1), 8-27.

Robinson, D., Perryman, S., \& Hayday, S. (2004). The drivers of employee engagement. Institute for Employment Studies.

Silva, A. (2016). What is Leadership? Journal of Business Studies Quarterly, 8(1), 1-5.

Slehr, E. S., \& Kueny, C. R. (2017). From the top-down: Transformational leadership considerations for health care organizations. Journal of Hospital Administration, 6(4), 19. 
Smith, G. R., \& Markwick, C. (2009). Employee Engagement: A Review Of Current Thinking. Institute For Employment Studies. https://www.employment-studies.co.uk /system/files/resources/files/469.pdf

Sorenson, S. (2013). How employee engagement drives growth. Gallup business journal, 1, 1-4.

Suifan, T. S., \& Al-Janini, M. (2017). The Relationship between Transformational Leadership and Employees' Creativity in the Jordanian Banking Sector. International Review of Management and Marketing, 7(2), 284-292.

Tannenbaum, R. J., Weschler, I. R., \& Massarik, F. (1961). Leadership and organization: A behavioral science approach. McGraw-Hill.

Thisera, T. J. R., \& Sewwandi, E. P. I. (2018). Transformational leadership and employee engagement in hospitality sector in Sri Lanka. Global Journal of Management and Business Research, 18(12), 27-33. https://journalofbusiness.org/index.php/GJMBR/article/view/2618/2519

Tims, M., Bakker, A. B., \& Xanthopoulou, D. (2011). Do transformational leaders enhance their followers' daily work engagement? The Leadership Quarterly, 22(1), 121-131.

Val, C., \& Kemp, J. (2012). Leadership Styles. The Ontario Journal of Outdoor Education, 24(3), 28-31.

Van Eeden, R., Cilliers, F., \& van Deventer, V. (2008). Leadership styles and associated personality traits: Support for the conceptualization of transactional and transformational leadership. South African Journal of Psychology, 38(2), 253-267.

Van Teijlingen, E. R., \& Hundley, V. (2001). The importance of pilot studies. Social Research Update, 35. http://sru.soc.surrey.ac.uk/SRU35.html

Van Teijlingen E, R., \& Hundley, V. (2002) The importance of pilot studies. Nursing Standard, 16(40),33-36.

Voon, M. L., Lo, M. C., Ngui, K. S., \& Ayob, N. B. (2011). The influence of leadership styles on employees' job satisfaction in public sector organizations in Malaysia. International Journal of Business, Management and Social Sciences, 2(1), 24-32.

Wang, Y., \& Hu, T. (2017). Transformational Leadership Behavior and Turnover Intention in China Physical Education. EURASIA Journal of Mathematics Science and Technology Education, 13(9), 6357-6368.

Webb, K. (2007). Motivating peak performance: Leadership behaviors that stimulate employee motivation and performance. Christian Higher Education, 6(1), 53-71. https://doi.org/10.1080/15363750600932890

Williamson, J. (2016, November 30). Labour: The missing piece in the industry 4.0 jigsaw. The Manufacturer. https://www.themanufacturer.com/articles/labour-the-missing-piece-inthe-industry-4-0-jigsaw/

Wiley, J. W. (2010). The Impact of Effective Leadership on Employee Engagement. Employment Relations Today, 37(2), 47-52.

Yahaya, R., \& Ebrahim, F. (2016). Leadership styles and organizational commitment: literature review, Journal of Management Development, 35(2), 190-216.

Zahid, K., \& Ozyapar, A. (2017). Leadership and Employee Engagement in organizations: an analysis on correlation [Master's thesis, Blekinge Institute of Technology School of Management]. Digitala Vetenskapliga Arkivet. http://www.divaportal.org/smash/get/diva2:1151272/FULLTEXT02.pdf 